\title{
Türkiye’de Yükselen Bir Turizm Çeşidi: Helal Turizm
}

\author{
Said KINGIR ${ }^{1}$ Nazlı KARDEŞ ${ }^{2 *}$ \\ ${ }^{1}$ Sakarya Üniversitesi, Turizm Fakültesi, Turizm İşletmeciliği Bölümü, SAKARYA \\ ${ }^{2}$ Sakarya Üniversitesi, , Sosyal Bilimler Enstitüsü, Turizm İşletmeciliği ABD, SAKARYA
}

\section{ÖZ}

Turizm, günümüzde gittikçe önemi artan sektörlerin başında gelmektedir. Dünya'da turizm her geçen gün büyümekte, alternatif turizm çeşitleri artmakta ve her yıl daha çok insan küresel düzeyde turizm hareketinin bir parçası haline gelmektedir. Teknolojide, iletişimde, refah seviyesin de, eğitim düzeyinde görülen ilerleme Müslüman kesimin yaşamdan beklentilerini artırmış ve Müslüman kesimi dinin gereklerine uyarak tatil yapmaya yönlendirmiştir. Turizm sektöründeki yoğun rekabet ortamı turistlerin taleplerinin çeşitlenmesine yol açmıştır. Bu gelişmelere bağlı olarak bir turistik ürün çeşidi olarak ortaya çıkan "Helal Turizm", gün geçtikçe önemi artan bir kavram olarak ortaya çıkmaktadır. Helal turizm, konaklama, seyahat, ulaşım, rekreasyon vb. turizm faaliyetlerinden doğan ihtiyaçların İslami kural ve inanışlara uygun şekilde karşılanması ile ilgili faaliyetlerdir. Bu araştırmanın amacı Türkiye'nin helal turizm açısından mevcut durumunu değerlendirmek, gün geçtikte rekabetin arttı̆̆ı helal turizm alanında Türkiye'nin potansiyelini kullanarak bu turizm çeşidinin nasıl geliștirebileceğine yönelik düşünceleri ortaya koymak ve gelecek çalışmalara yol göstermektir. Bu amaç doğrultusunda konuyla ilgili geniş bir literatür taraması yapılarak helal turizmin kavramsal çerçevesi ortaya konmuş ve derinlemesine incelenen literatür çalışmaları, istatistik verileri ile Türkiye'nin mevcut kültürü ve Müslüman bir ülke olmasına rağmen diğer ülkelerden geride olduğu ve mevcut potansiyelini iyi kullanamadığı sonucuna varılmıştır. Bu sonuca yönelik öneriler getirilmiştir.

Anahtar kelimeler: Helal turizm, Türkiye, Alternatif turizm

\section{A Rising Tourism Types in Turkey: Halal Tourism}

\begin{abstract}
Tourism is at theforefront of increasingly important sectors today. Since alternative tourism types are increasing and more people participate in tourism activity every year, world tourism piegrows day by day. The developments in technology, communication, and education and the increase in the overall welfare level has increased the material expectations of Muslim tourists and this led the Muslims to look for alternative vacation options that meet requirements set by the religion. Intensive competition in the tourism sector has led to diversification of tourism. Depending on those developments, a variety of tourism products emerged as "Halal
\end{abstract}


Tourism" which has increasingly importance day by day and and becomes a hot topic in academic literature. Halal tourism includes all touristic businesses that satisfy the needs of all tourism activities such as recreation, accommodation, travel, transportation based on the Islamic rules and regulations. The purpose of thisresearch is to assess the present situation of Turkey for halal tourism and to put forward thoughts on how to develop halal tourism by using the potential of Turkey to guide for future works. For this purpose, a conceptual framework of halal tourism has been established by conducting a comprehensive literature search. As a result of this research, it is concluded that even though the thev ast majority of the people in Turkey are Muslim, halal tourism market is very small when compared toot her countries. In the conclusion, we have broughts ome suggestions to improve the halal tourism in Turkey.

Keywords:Halal tourism, Turkey, Alternative tourism

\section{GíRIŞ}

Turizm faaliyeti, ülke dışına veya ülke içine yapılan seyahatlere yerli veya yabancı turistlerin katılımıyla gerçekleşen faaliyetlerin tümüdür. Turizm endüstrisi gerek Türkiye'de gerekse dünyada son derece hızlı büyüyen ve gelişen endüstrilerden biri olmuştur. Ülkelerin refah düzeylerinin artması, eğitim seviyelerinin artması, boş zamanlarının artması gibi etkenlerle alternatif turizm çeşitleri artmıştır.

“Özellikle son yıllarda, dini hassasiyeti yüksek Müslümanlar için helal ürün, helal hizmet ve helal süreçlere ilişskin olarak dünyada gelişen bir algı ve talep görülmektedir (Arpacı ve Batman, 2015, s.73)”. Günümüzde daha bilinçli hale gelen insanlar tatil tercihlerini yaparken daha dikkatli davranmaya başlamışlardır ve tatil seçimlerini yaparken bazı faktörleri göz önünde bulundurmaya başlamışlardır. Tüketicilerin satın alma kararları kültürel ve sosyal çevre, yaşam şekli, aile, kişisel ve psikolojik ve din faktörlerinden etkilenmektedir (Köleoğlu, Erdil ve Gezen, 2016, s.364).Din faktörünün tatil seçimlerinde önemli bir yer tutması ve Müslüman turistlerin "helal" kavramına önem vermesi ile birlikte "helal turizm" kavramı oluşmuştur. Helal turizm son yıllarda Literatür de önemli bir yer edinmiştir. Yapılan araştırmalara göre uluslararası turizm pazarı son dönemde yıllık ortalama yüzde 3,8 büyürken, helal turizm pazarı yüzde 4,8 büyüme kaydettiği görülmüştür (Arpacı ve Pamukçu, 2015, s.320, Sarışık ve Pamukçu, 2016, s.102, Tanrısever vd., 2015, s.464). Helal turizmin büyüme oranına bakıldığında ve Dünya'da Müslüman sayısının günden güne artması, Müslümanların sahip olduğu gelir seviyelerinin artması göz önünde bulundurulduğunda helal turizm çok önemli bir pazar haline geldiği görülmektedir. Türkiye'nin helal turizm potansiyelinin yüksek olması, Müslüman nüfusun yoğunluğunun fazla olması göz önüne alındığında helal turizmin tüm yönleriyle ele alınarak araştırılması, bu sektöre yönelik gerekli önemin verilmesi ve iyileştirmelerin yapılması gerekmektedir.

\section{LITERATÜR TARAMASI}

\subsection{Turizm ve Din İlişkisi}

Turizm; "İnsanların sürekli yaşadıkları yer dışında yaptıkları seyahat ve gittikleri yerlerde geçici konaklamalarından doğan ihtiyaçların karşılanması ile ilgili faaliyetlerdir (Zengin, 2015, s.38)". Başka bir tanıma göre ise;" Kazanç sağlama amacına yönelik olmamak ve sürekli yerleşmemek koşulu ile yabancıların bir yere seyahatleri ve orada konaklamaları sonucunda ortaya çıkan olayların tümüdür (Zengin, 2015, s.39)”. Genel olarak bakıldığında turizm olgusunun oluşabilmesi için bulunduğu yer dışında bir yere gitmesi, orada para harcaması ve en az bir gece konaklama yapması gerekmektedir. Bunların oluşabilmesi için ise, turistin boş zamana, gelire ve motivasyona sahip olması gerekmektedir. Turizm kavramı eğlenme, rahatlama, aile, iş, spor, eğitim din gibi amaçlarla yapılan seyahatlerden oluşur. Din kavramı ise; akıl sahibi insanları kendi tercihleriyle bizzat hayırlı olan şeylere götüren ilâhî bir kanundur (www.diyanet.gov.tr). Din, birey ve toplum hayatını düzenleyen bütün ilişkiler sistemi içinde varlığını sürdürür. Bu anlamda bir toplumun din anlayışı, iman esasları ve ibadet uygulamaları, kişilerin ve toplumun gündelik hayatına, tatil anlayışına, düşüncelerine 
doğrudan veya dolaylı olarak yansır (Özdemir, 2015, s.51). İnsanlık tarihinde seyahat kavramı ile dinin yakın bir ilişkisinin olduğu bilinmektedir. "İslam dini insanların, geçmiş medeniyetlerin tarihine ve kültürel mirasına ibret nazarıyla bakmaların emretmektedir. İnancın temellendirilmesi hususunda Kur'an'ın seyahate dönük tavsiyeleri dikkate alındığında Müslümanların turizm faaliyetlerinde aktif olmaları gerektiği sonucuna ulaşmak mümkündür (Süt, 2014, s.480).”Bu açıklamalara bakıldığında, turizmin en önemli kavramlarından biri seyahattir.

Turizmin tanımı yapılırken bulunduğu yerden başka bir yere gitmek ifadesi kullanılmaktadır. İnsanlar çeşitli nedenlerle sürekli seyahat etmişlerdir. Eski çağlarda seyahat etmek lüks bir kavram olduğu için seyyahlar dikkat çekmiştir (seyyah Marco Polo, Arap seyyah İbniBatuta ve Türk seyyah Evliya Çelebi). Bunların yanı sıra, şifa bulmak amaçlı yapılan seyahatler ve kutsal yerlerin ziyaretleri amaçı yapılan seyahatler ön plana çıkmıştır, özellikle hac görevlerinin yerine getirilmesi seyahat açısından önemli bir hareketlilik sağlamıştır. Öte yandan, dini yaymak adına yapılan seyahatlerde, seyahat sektörünün ilk numunelerini oluşturmaktadır (Koçyiğit, 2011, s.126). Bu gelişmeler doğrultusunda baktığımızda, turizmin ortaya çıkışına etki eden faktörleri şu şekilde sıralayabiliriz (Kaynak ve Sezgin, 2005, s. 350);

- $\quad$ Ekonomik etkenler,

- Toplumsal etkenler,

- $\quad$ Kültürel etkenler,

- $\quad$ Bilimsel etkenler.

Dini boyutta ise, etkili olan faktörler şunlardır;

- Dini yerleri ziyaret,

- $\quad$ Kutsal kentleri ziyaret,

- Dini toplantılara katılmak,

- Dini törenlere katılmak.

Bu gelişmelere baktığımızda din kavramının turizm üzerinde oldukça önemli etkileri olduğunu görebiliriz. Turizm modern görünümlü bir kavram olsa da, temelde seyahat olayına dayanmaktadır. Kuran-ı Kerim'de seyahat ve benzeri kavramlarla ifade edilmektedir. Kuranda geçen ayetlere ve seyahatin çıkış nedenlerine baktığımızda dinin turizm üzerindeki ve Müslümanların seyahat etmesi üzerindeki etkisi açıç̧a görülmektedir (Koçyiğit, 2011, s.128). Günümüzde ise, teknolojinin gelişmesi, artan refah seviyesi, otellerin rekabetlerinin artması, müşteri memnuniyetinin ve hizmet kalitesinin ön planda tutulmaya başlanması ile birlikte farklı istek ve ihtiyaçlara sahip müşteriler ve yeni hizmet talepleri ortaya çıkmıştır. Son yıllarda ise, dinin emirlerine uyarak yaşamaya çalışan Müslüman kesimlerin helal kavramını benimseyerek taleplerini bu yönde arttırdıkları görülmektedir (Arpacı, 2016, s.1056).

\subsection{Helal Turizm Kavramı}

Günümüzde gelişen teknoloji, artan refah seviyesi, gelirin yükselmesi, boş zamanın artması gibi nedenlerle birlikte günümüz tüketicisi daha bilinçli hale gelmiştir. Tüketici bir ürünü satın alırken daha seçici ve dikkatli davranmaktadır. Satın alma davranışları üzerine yaş, cinsiyet, dünya görüşü ve eğitim gibi bireysel özelliklerin yanı sıra, din ve inancın etkileri bulunmaktadır. Aynı zamanda "birer tüketici olan insanların mensup oldukları dinleri, inançları onları nasıl yaşayacakları, nasıl tüketecekleri neleri yapıp, neleri yapmamaları konusunda yönlendirmektedir (Akyol, 2014, s.172). Tüketiciler bir ürün satın alırken dini inançlarına göre hareket ederek "bazı ürünleri sırf dini inançlarına uygun olduğu için satın alırken, bazı ürünleri de yine sırf dini inançlarına uygun olmadığı için satın almayabilirler (Kurtoğlu ve Çiçek, 2013, 
s.181)". Örneğin; Müslümanların domuz eti yemesi haram sayıldığı için domuz eti satan yerleri ve domuz etini tercih etmezler. Yine benzer şekilde alkol tüketimi İslam dininde haram olarak görüldüğü için, tüketiciler alkol satışı yapılan bir yerden ürün almamayı tercih edebilirler. Bunun sonucu olarak da haram karşıtı olan helal kavramı ortaya çıkmaktadır.

Helal ve haram kavramı: İslamiyet'e göre "Helâl" Müslümanlar için yapılmasına müsaade edilenler (Baran ve Batman, 2015, s. 169), başka bir deyişle helal (mahzursuz) gıda, çiftlikten çatala kadar tüm yönüyle İslâmî kurallara uygun olarak hazırlanan gıdayı ifade eder. Daha geniş bir açıklamayla Helal Gıda, bitkisel, hayvansal, kimyasal ya da mikrobiyal kaynaklı, gıda ürünlerinin hammadde, işlem yardımcı maddeleri, bileşenleri, katkı maddeleri, işleme yöntemleri, işletme koşulları ve ek olarak ambalajlarının İslâmî kurallara uygunluğunun ifadesidir (Batu, 2012, s.52). "Haram" ise, yapılması yasak olan şeyler anlamına gelmektedir (Baran ve Batman, 2015, s.169), TDK ise, helal kavramını dinin kurallarına aykırı olmayan, dinî bakımdan yasaklanmamış olan, haram karşıtı şeklinde tanımlamışıı (www.tdk.gov.tr).

"Turizm, insanların sürekli yaşadıkları yer dışında yaptıkları seyahat ve gittikleri yerlerde geçici konaklamalarından doğan ihtiyaçlarının karşılanması ile ilgili faaliyetlerdir (Zengin ve Demirkol, 2015, s.38)." Helal turizm ise, turizm tanımında geçen "konaklamalardan doğan ihtiyaçların İslami kural ve inanışlara uygun şekilde karşılanması ile ilgili faaliyetlerdir (Arpacı ve Batman, 2015,s.186)." Son yıllarda yükselişe geçen helal turizm, tüketicinin talebine karşllık İslami kurallara uygun bir şekilde arzlar sunan ve özellikle gıda konusunda helal sertifikalı ürünlerin kullanıldığı bir turizm çeşidi haline gelmiştir.

Helal turizmde amaç, Müslüman turistlerin inançları ve dini kurallarını bir bütün halinde talep eden tüketiciye sunmaktır (Büyükşalvarcı vd., 2016, s.1058). Helal turizmde sadece İslami, muhafazakar ya da helal konseptli konaklama tesislerinden bahsetmek yanlış olur. Helal turizm bir bütündür ve helal turizmin doğrudan ilişkili olduğu faaliyetler şu şekilde sıralanabilir (Oflaz, 2015, s.45);

- Helal finans,

- Helal yiyecek içecek işletmeleri,

- Helal seyahat acenteleri,

- Helal transferlulaşım,

- Helal konaklama tesisleri,

- Helal eğlence.

Dinin gereklerini, kurallarını yerine getirmeye çalışan tüketici grubuna yönelik, Türkiye'de 1996 yılından itibaren İslami oteller ortaya çıkmaya başlamışıı (Pamukçu ve Arpacı, 2015, s.32). Özellikle 2002 yılından itibaren "helal turizm" olarak bilinen ve dini hassasiyetlerini dikkate alan kesimin taleplerine uygun olarak tasarlanan konaklama işletmelerinin sayısı artmaya başlamıştır ( Yeşiltaş, Cankül ve Temizkan, 2012, s.196).

\subsection{Helal Otel Kavramı}

Helal otel, otel tanımında olduğu gibi asli fonksiyonu geceleme ihtiyacını sağlamak olan ve bu hizmetin yanında yeme, içme ve eğlenme ihtiyaçlarını İslami kural ve inançlara uygun biçimde karşılayan tesislerdir (Pamukçu ve arpacı, 2015, s.322). Helal oteller sadece yiyecek ve içecek sunulması ile sinırlı değildir. Otellerde sunulan hizmet şeklinin de helal kavramına uygun olması gerekmektedir (Met vd., 2013, s.653).

Helal turizm konseptin de hizmet veren otel işletmeleri hizmet verdikleri turist profilinin niteliğinden dolay1 bir takım farklı özelliklere sahiptirler. Bu tür turistlerin otel tercihinde öne çıkan nitelikler şunlardır; Temiz oda ve çevre, Helâl yiyecek-içecek imkânları, samimi bir misafirperverlik anlayışı ve servis sistemi, işletmelerin ibadetleri yerine getirebilme konusunda sunduğu imkanlar, alkolsüz çevre, menüde çeșitlilik, 
yüzme olanakları, zengin sosyal aktivite imkânları, kadınlar için ayrı alanlarda rekreasyon olanaklarıdır (Tekin ve Yılmaz: 2016, s.2048). Helal turizm alanında yapılan çalışmalarda (Tekin ve Yılmaz, 2016; Boğan, Batman ve Sarışık, 2016; Met, Özdemir, Aydemir, 2013; Hacığlu vd., 2015; Pamukçu ve Arpac1, 2015; Boğan, Batman ve Sarışık, 2016; Özaltaş Serçek, Karakaş ve Serçek, 2017) bu tür konsepte sahip otellerin taşıması gereken nitelikler belirlenmiştir. Helal turizm konseptine hizmet veren konaklama işletmelerine ilişkin olarak tespit edilen nitelikler aşağıdaki Tablo 1'de sunulmuştur.

Tablo 1: Helal konseptli otellerin Sahip Olması Gereken Nitelikler

\begin{tabular}{|c|c|}
\hline Yiyecek-içecek & $\begin{array}{l}\text { - Yiyeceklerinin güvenilir (Helal) olması, } \\
\text {-Tesislerde alkollü içecek servisinin olmaması, } \\
\text {-Helâl gıda sertifikası olması, }\end{array}$ \\
\hline Personel & $\begin{array}{l}\text { - Personelin İslami ilkelere aykırı giyinmemesi } \\
\text {-Personellerin Müslüman olması, } \\
\text {-Personele ibadetlerini yerine getirebilmeleri için imkan sunulması, } \\
\text {-Kadın misafirlere ait alanlarda kadın personelin erkek misafirlere ait alanlarda erkek personelin } \\
\text { istihdam edilmesi, }\end{array}$ \\
\hline Odalar & $\begin{array}{l}\text { - Yatak ve tuvaletlerin yönünün kıbleye göre düzenlenmiş olması, } \\
\text { - Her odada seccade ve Kur'an'ın olması, } \\
\text {-Misafir profili açısından uygunsuz TV kanalları olmaması } \\
\text {-Banyoların abdest almaya uygun yapıda olması, }\end{array}$ \\
\hline Eğlence yapısı & $\begin{array}{l}\text { - İslami ilkelere uygun eğlence faaliyetler } \\
\text { - Havuz, Spa gibi alanların bay -bayan ayrı olması, } \\
\text {-Disko, gece kulübü vb. olmaması } \\
\text { - Çocuklar için İslami aktiviteler olması, } \\
\text {-İşletmenin denize sahili var ise kadın ve erkekler için ayrı deniz imkanları olması. }\end{array}$ \\
\hline $\begin{array}{l}\text { Otel yapısı ve } \\
\text { finansal yapı }\end{array}$ & $\begin{array}{l}\text {-İslami finansman kaynağının olması, } \\
\text {-Ramazan ayında iftar ve sahur imkânının olması, } \\
\text {-otele gelen misafirlerin İslami usullere uygun giyinmesi, } \\
\text {-İslami kurallara uygun sosyal sorumluluk uygulamaları gerçekleştirilmesi, } \\
\text {-Hayırseverlikle alakalı bağış uygulamalarına dahil olunması, } \\
\text {-Otel içerisinde hayvan ve insan figürü bulunan dekoratif ürünlerin olmaması, } \\
\text {-Alkolsüz çevre olması, }\end{array}$ \\
\hline
\end{tabular}


Kaynak: (Tekin ve Yılmaz, 2016, s.2049), ( Boğan, Batman ve Sarışık, 2016) (Met, Özdemir ve Aydemir,2013, s.653), ( Hacıoğlu vd., 2015, s.492), (Pamukçu ve Arpacı, 2015, s. 323), (Boğan, Batman ve Sarışık, 2016, s.1435; Bilgin ve Karakaş, 2017)

Cankül, Yeşiltaş ve Temizkanın yapmış olduğu otel seçiminde dini hayat tarzlarının etkisi adlı çalışmada aşağıdaki bulguları elde etmiştir. İslami otelde konaklayanların otel seçimine etki eden en önemli faktörler sirasiyla;

- $\quad$ Yiyeceklerde domuz eti olmaması $(4,92)$,

- Bayanlar için ayrı bir havuz olması $(4,78)$,

- Dini emirlere uygun ürünler $(4,73)$,

- $\quad$ Hijyen $(4,72)$,

- $\quad$ Erkekler için ayrı bir havuz olması $(4,71)$,

- Güvenlik ve emniyet $(4,70)$,

- $\quad$ Alkollü içecek bulunmaması $(4,70)$,

- $\quad$ Güven $(4,68)$,

- Güler yüzlü ve yardımsever personel $(4,68)$,

- $\quad$ Kalite $(4,67)$ faktörleri olarak görülmektedir.

$\mathrm{Bu}$ çalışmada otel seçimini en fazla etkileyen bu ilk 10 faktörün önemli bir kısmının İslami otellerde konaklayanlar için dini emir ve yasaklarla ilgili olması dini hayat tarzlarının bu müşterilerin tercihlerinde etkili olduğu anlamına gelebilir (Cankül, Yeşiltaş ve Temizkan 2012, s.207). Gelişmekte olan teknoloji, artan refah seviyesi, buna bağlı olarak artan eğitim seviyesi ile birlikte Müslümanların dünyevi beklentileri ve turizm eğilimleri artmıştır. Turizm sektöründe bulunan otellerin artan rekabet ortamı ile birlikte turistlerin talepleri de çeşitlenmiştir (Boğan, Batman ve Sarışık, 2016, s.1425; Bilgin, 2017). Bu nedenle günümüzde helal turizm sürekli gelişmekte olan ve ekonomik olarak önemli bir paya sahip olan bir turizm çeşidi olarak ele alındığında müşteri tercihlerini etkileyen faktörler memnuniyeti sağlamak için önemle incelenmeli ve oteller tarafindan uygulanmalıdır.

\subsection{Helal Turizmin Türkiye'deki Uygulamaları}

Dinin, insan hayatındaki birçok davranışı etkileyen çok temel bir faktör olduğuna dair literatürde çeşitli çalışmalar yapılmıştır (Cankül,Yeşiltaş ve Temizkan, 2012; Yücebaş, Semiray, 2012; Süt, Abdullah, 2014; Koçyiğit, Hikmet, 2011). Yine Yeşiltaş vd. yaptığı çalışmada dinin otel seçimine ve tatil seçimine etkisi olduğu sonucuna varılmıştır. Türkiye'nin ise dini çoğunluğu İslam olduğu için helal turizmin potansiyeline sahip bir ülkedir."Laik bir yönetim anlayışına sahip olan ve nüfusunun \%98'nin Müslüman olduğu Türkiye'de, Müslüman-Dini turizm faaliyetleri 1990'lı yıllarda başlamış ve bugün İslam dininin gerektirdiği konsepte sahip olan otellerde de önemli bir artış meydana gelmiştir (Boğan vd., 2016)". Dünya Bankası ve Dünya Turizm Örgütünün (WTO) tespitlerine göre; turizm sektörü son 10 yllda 3 kat büyümüş olup, gelecek 20 yıl içerisinde ise "Dünyanın en büyük endüstrisi" haline gelmesi beklenmektedir(Sarışık ve Pamukçu, 2016, s.100). Ayrıca hac ve umre ziyaretleri dışında, 2019 yılına gelindiğinde helal turizmden elde edilecek gelirin 238 milyar doları aşacağı belirtilmektedir (whtsexpo.com). Bu bilginin yanında 2050 yılında Müslüman nüfusunun dünyanın \%73'lük kısmını oluşturacağı düşünülmektedir (Boğan, Batman ve Sarışsk, 2016, s.1438). Yapılan araştırmalara göre uluslararası turizm pazarı son dönemde yıllık ortalama yüzde 3,8 büyürken, helal turizm pazarı yüzde 4,8 büyüme kaydettiği görülmüştür (Arpacı ve Pamukçu,2015, s.320, 
Sarışık ve Pamukçu,2016, s.102, Tanrısever vd., 2015, s.464). Bu bilgilere ek olarak Dünya'da Müslüman sayısının günden güne artması, Müslümanların sahip olduğu gelir seviyelerinin artması göz önünde bulundurulduğunda helal turizm çok önemli bir pazar haline gelmektedir. Aşağıdaki tabloda dini İslam olan veya büyük bir kısmını Müslümanların oluşturduğu 63 ülke verilmiştir.

Tablo.2: Dini İslam olan veya Nüfusun büyük bir kısmını Müslümanların oluşturduğu ülkeler

\begin{tabular}{|c|c|c|}
\hline 1-Afganistan & 24-Gine basau & 47-Mozambik \\
\hline 2-Azerbaycan & 25-Gine & 48-Nijerya \\
\hline 3-Bangladeş & 26-Guyana & 49-Umman \\
\hline 4-Benin & 27-İran & 50-Türkmenistan \\
\hline 5-Bosna Hersek & 28-Katar & 51-Yemen \\
\hline 6-Burkino Feso & 29-Kırgızistan & 52- Tacikistan \\
\hline 7-Brunei & 30-KKTC & 53-Malezya \\
\hline 8-Cezayir & 31-Özbekistan & 54-Makedonya \\
\hline 9-Çad & 32-Senegal & 55-Arnavutluk \\
\hline 10-Endonezya & 33-Somali & 56-Bahreyn \\
\hline 11-Fildişi sahili & 34-Surinam & 57-Batı sahra \\
\hline 12-Gabon & 35-Suudi Arabistan & 58-Birleşikarap emirlikleri \\
\hline 13-Tunus & 36-Togo & 59-Pakistan \\
\hline 14-Uganda & 37-Irak & 60-Sierra Leone \\
\hline 15-Ürdün & 38-Kamerun & 61-Sudan \\
\hline 16-Mali & 39-Kazakistan & 62-Suriye \\
\hline 17-Moritanya & 40-Kosova & 63-Türkiye \\
\hline
\end{tabular}




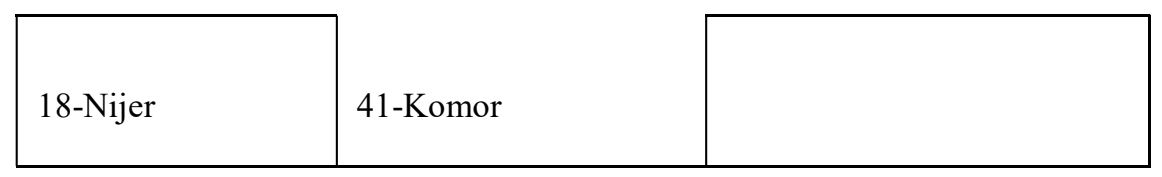

\begin{tabular}{|l|l|l|}
\hline 19-Cibu & 42-Lübnan & \\
\hline 20-Elritre & 43 -Kuveyt & \\
\hline 21-Filistin & $44-$ Libya & \\
\hline 22-Fas & $45-$-Maldivler & \\
\hline 23-Gambiya & $46-$ Misır & \\
\hline
\end{tabular}

Kaynak: www.guzelbil.com:2015, www.bilgibirikimi.com: 2015

$\mathrm{Bu}$ ülkelerin nüfus artışı, her yıl artmasıyla birlikte satın alma gücü yüksek toplumların helal turizm talebini önemli derecede etkilediği ve talebin günden güne büyümesinde önemli faktörlerden biri olduğu görülmüsștür. Bunun yanında Türkiye'ye seyahat eden Müslümanların 2012-2015 yılları sayısına bakıldığında (Tablo 3) sayının yıllar içerisinde sürekli arttığı görülmektedir. Aşağıda verilen tablo incelendiğinde Müslümanların her yıl daha çok turizm faaliyetlerine katıldığının ve turizmi daha çok benimsediklerinin bir göstergesi olarak kabul edilebilir. Her yıl devam eden bu artış sektöre gerekli önem verildiğinde ve gerekli iyileştirmeler yapıldığında Türkiye'nin 2023 hedeflerine ulaşmasında önemli katkıda bulunabilir. Türkiye'ye seyahat eden Müslümanların dağılımını gösteren tablo helal turizme gereken önemin verilmesini bir kez daha göstermektedir.

Tablo 3: Türkiye'yi Ziyaret Eden Müslümanların 2012-2015 Yılları Arası Dağılımı

\begin{tabular}{|c|c|c|c|c|c|c|c|c|}
\hline & YIL & YIL & YIL & YIL & $\begin{array}{l}\text { MILLIYET } \\
\text { PAYI(\%) }\end{array}$ & $\begin{array}{l}\text { MILLIYET } \\
\text { PAYI(\%) }\end{array}$ & $\begin{array}{l}\text { MİLLIYET } \\
\text { PAYI(\%) }\end{array}$ & $\begin{array}{l}\text { MILLIYYT } \\
\text { PAYI(\%) }\end{array}$ \\
\hline ÜLKELER & 2012 & 2013 & 2014 & 2015 & 2012 & 2013 & 2014 & 2015 \\
\hline TUNUS & 86595 & 91638 & 100612 & 102341 & 0,27 & 0,26 & 0,27 & 0,28 \\
\hline MISIR & 112025 & 107437 & 108762 & 100040 & 0,35 & 0,31 & 0,30 & 0,28 \\
\hline SUDAN & 8161 & 9319 & 10714 & 11434 & 0,03 & 0,03 & 0,03 & 0,03 \\
\hline BAHREYN & 13342 & 16230 & 24305 & 32476 & 0,04 & 0,05 & 0,07 & 0,09 \\
\hline KATAR & 13971 & 18630 & 29743 & 35832 & 0,04 & 0,05 & 0,08 & 0,10 \\
\hline
\end{tabular}




\begin{tabular}{|c|c|c|c|c|c|c|c|c|}
\hline LİBYA & 213890 & 264266 & 267501 & 234762 & 0,67 & 0,76 & 0,73 & 0,65 \\
\hline İRAN & 1186343 & 1196801 & 1590664 & 1700385 & 3,73 & 3,43 & 4,32 & 4,69 \\
\hline YEMEN & 11826 & 17354 & 26033 & 24237 & 0,04 & 0,05 & 0,07 & 0,07 \\
\hline CEZAYİR & 104489 & 118189 & 160052 & 171873 & 0,33 & 0,34 & 0,43 & 0,47 \\
\hline FAS & 77804 & 82579 & 89562 & 109775 & 0,25 & 0,24 & 0,24 & 0,30 \\
\hline IRAK & 533149 & 730639 & 857246 & 1094144 & 1,68 & 2,09 & 2,33 & 3,02 \\
\hline PAKİSTAN & 28394 & 34170 & 48420 & 59700 & 0,09 & 0,10 & 0,13 & 0,16 \\
\hline $\begin{array}{l}\text { SUUDİ } \\
\text { ARABİSTAN }\end{array}$ & 175467 & 234220 & 341786 & 450674 & 0,55 & 0,67 & 0,93 & 1,24 \\
\hline ÜRDÜN & 102154 & 102871 & 131329 & 162866 & 0,32 & 0,29 & 0,36 & 0,45 \\
\hline AZERBAYCAN & 593238 & 630754 & 657684 & 602488 & 1,87 & 1,81 & 1,79 & 1,66 \\
\hline KIRGIZISTAN & 42866 & 64905 & 81941 & 88369 & 0,13 & 1,79 & 0,22 & 0,24 \\
\hline TÜRKMENISTAN & 135168 & 148709 & 180395 & 174330 & 0,43 & 0,43 & 0,49 & 0,48 \\
\hline TACÍKİSTAN & 22823 & 27174 & 34678 & 31917 & 0,07 & 0,08 & 0,09 & 0,09 \\
\hline ÖZBEKİSTAN & 105976 & 129292 & 143354 & 143331 & 0,33 & 0,37 & 0,39 & 0,40 \\
\hline ENDONEZYA & 56113 & 57385 & 59486 & 56867 & 0,18 & 0,16 & 0,16 & 0,16 \\
\hline KUVEYT & 65167 & 88238 & 133128 & 174486 & 0,21 & 0,25 & 0,36 & 0,48 \\
\hline $\begin{array}{l}\text { B.ARAP } \\
\text { EMİRLIĞİ }\end{array}$ & 48071 & 52424 & 53736 & 51600 & 0,15 & 0,15 & 0,15 & 0,14 \\
\hline LÜBNAN & 144491 & 143629 & 161274 & 197552 & 0,45 & 0,41 & 0,44 & 0,55 \\
\hline ARNAVUTLUK & 59565 & 65113 & 76273 & 80032 & 0,19 & 0,19 & 0,21 & 0,22 \\
\hline
\end{tabular}




\begin{tabular}{|c|c|c|c|c|c|c|c|c|}
\hline KAZAKİSTAN & 380046 & 425773 & 437971 & 423744 & 1,20 & 1,22 & 1,19 & 1,17 \\
\hline MALEZYA & 41169 & 55139 & 69968 & 69616 & 0,13 & 0,16 & 0,19 & 0,19 \\
\hline BANGLADEŞ & 6652 & 8856 & 12706 & 12212 & 0,02 & 0,03 & 0,03 & 0,03 \\
\hline TOPLAM & 4369035 & 4921779 & 5889323 & 6397083 & 13,75 & 14,10 & 15,99 & 17,65 \\
\hline $\begin{array}{l}\text { TÜM } \\
\text { ÜLKELERIN } \\
\text { TOPLAMI }\end{array}$ & 31782832 & 34910098 & 36837900 & 36244632 & 100 & 100 & 100 & 100 \\
\hline
\end{tabular}

Kaynak: Boğan, E., Batman O. ve Sarışık, M. (2016). Helal turizmin kavramsal çerçevesi ve Türkiye'de ki uygulamalar üzerine bir değerlendirme, 1432 .

MasterCard veCrescentRating' in $2016 \quad$ yılın $\quad$ da $\quad$ yayınladığı, 130 hedefülkedeyiyeceklerinİslamideğerlereuygunluğu, ibadetimkanlarınınbulunmasıgibibirçokkriterindeğerlendirildiği "MüslümanlarınSeyahatTercihleriEndeksi" raporunda, Müslümanturistlerin en çoktercihettiğiüçülkesırasıylaMalezya, BirleşikArapEmirlikleriveTürkiyeolarakaçıklanmıştır.

Tablo.4: GMSE 2016 Raporunagöre ilk 5'e giren İslam Ülkeleri

\begin{tabular}{|l|l|l|l|}
\hline SEVIYE & GMSE(2016) SEVIYESI & DESTINASYON & PUAN \\
\hline 1 & 1 & Malezya & 81.9 \\
\hline 2 & 2 & Birleşik Arap Emirlikleri & 74.7 \\
\hline 3 & 3 & Türkiye & 73.9 \\
\hline 4 & 4 & Endonezya & 70.6 \\
\hline 5 & 5 & Katar & 70.5 \\
\hline
\end{tabular}

Kaynak:MasterCard-CrescentRating Global Muslim Travel Index-2016.

Tablo.5:GMSE 2016 Raporunda ilk 5'e giren İslam olmayan Ülkeler 


\begin{tabular}{|l|l|l|l|}
\hline SEVIYE & GMSE(2016) SEVIYESI & DESTINASYON & PUAN \\
\hline 1 & 8 & Singapur & 68.4 \\
\hline 2 & 20 & Tayland & 59.5 \\
\hline 3 & 21 & Birleşik Krallık & 59.0 \\
\hline 4 & 30 & Güney Afrika & 53.1 \\
\hline 5 & 31 & Hong kong & 53.0 \\
\hline
\end{tabular}

Kaynak:Master Card-CrescentRating Global Muslim Travel Index- 2016.

2016 yılında Master Card-Crescent Rating'in yaptığı bu araştırmaya gore Müslüman tatilcilerin en çok tercih ettiği üç ülke Malezya, Birleşik Arap Emirlikleri ve Türkiye olarak görülmektedir ve araştırmanın sonucunda 81.9 puanla Malezya 1. sırada, 74.7 puanla Birleşik Arap Emirlikleri 2.sırada ve 73.9 puanla Türkiye 3.sırayı almıştır. 2015 yılının verilerine bakıldığında ise, Türkiye 73.8 puan ile 2.sıradadır (Boğan vd., 2016, s.1434). Türkiye geçen yıla gore sıralamada 1 sıra geriye düşse de, puanını 0.1 oranında artırmıştır. Müslüman olmayan ülkelerin puan durumuna bakıldığında Singapur 68.4 puan le 8.sirada, 59.5 puan ile Tayland 20.sırada, Birleşik Krallıklar ise 59.0 puan ile 21. Sırada yer almıştır. Genel olarak bakıldı̆̆ında ise puanlamaların ve sıralamaların gayet iyi olduğu Müslüman sayılarının az olmasına rağmen "Helal turizme" önem verdikleri sonucuna ulaşılabilir.

Türkiye'de helal turizmi geliştirme doğrultusunda örgütlü çabaların olmamasına rağmen listed üst sıralarda yer alması ülkenin potansiyelinin gereğidir. Bu pazara gelişmesine yönelik adımlar attığında kısa sürede en iyi helal turizm uygulayan ülke konumuna gelebilir puanını ve sırasını yükseltebilir (Sarışık ve Pamukçu, 2016, s.103). Günümüzde Türkiye'de yaşanan terror olayları, Rusya ile yaşanan kriz gibi olaylar turizmi olumsuz yönde etkilemiş ve bazı otellerin kapanmasına neden olmuştur.Turizm sektöründe meydana gelen bu düşüş "helal turizm" sektörünü pek etkilememiş hatta aksine bu sektörün beklenenden daha fazla büyümesine olanak sağlamıştır. 2016 yılında irili ufaklı 20 ye yakın islami otel açılmıştır (www.islamitatilyerleri.net,www.islamihotels.com).

Türkiye gerek dini, gerek kültürü ile helal turizm açısından geliştirilebilecek, geniş bir potansiyele sahiptir. Turizmin ise temelinde müşteriyi memnun etmek vardır (Zengin, 2016, s.41). Bu nedenle Türkiye mevcut potansiyelini iyi kullanabilmesi için öncelikle turistlerin beklentilerini anlamalı ve bunlara cevap vermelidir. Met, Özdemir ve Aydemir'in 2013 yılında yaptığı "İslami otellerin ürün nitelikleri: Türkiye Örneği" adlı çalışmada misafirlerin işletmeden beklentileri önem derecelerine göre şu şekilde sıralanmıştır;

- $\quad$ Alkollü içeceklerin olmaması,

- $\quad$ Yiyeceklerin İslami usullere uygun olması,

- $\quad$ Odalarda kuran, seccade, kıble yön pusulası vb. bulunması,

- Kadın erkek havuzlarının ayrı olması,

- Yeterli büyükte mescit olması, 
- Evlilik belgesi olmayan çiftlerin otele alınmaması,

- Müzikli eğlence ortamlarının cinslere göre ayrı olması,

- Dini ve kültürel aktiviteler için toplantı salonlarının olması,

- Ortak mekanlarda yabancı müzik yayını olmaması,

- $\quad$ Alaturka tuvaletlerin olmas1,

- $\quad$ Erkeklere hem cinslerinin hizmet etmesi,

- $\quad$ Personelin İslami usullere göre giyinmeleri,

- Spor aktivitelerinin kadın ve erkekler için ayrı olması,

- Dini içerikli boş zaman değerlendirme aktivitelerinin olması,

- Dini semboller ve dekor malzemelerin kullanılması,

- Kadınlara hem cinslerinin hizmet etmesi,

- Tüm müşterilerin İslami usullere uygun giyinmesi(çocuklar hariç),

- $\quad$ Personelin dindar olanlardan seçilmesi,

- Gayri Müslimlerin otele alınmaması olarak belirlenmiştir.

Tekin ve yılmazın 2016 yılında yaptığı; "İslami turizm konseptinde hizmet veren konaklama işletmeleri üzerine bir inceleme" adlı çalışmada ilginç bir bulgu olarak işletmelerin tamamı yiyecek-içecek üretiminde Helâl kriterleri göz önünde bulundurduklarını ifade etmişlerdir ancak "Helâl gıda sertifikanız var mı?" sorusuna "evet" cevabını verebilen işletmelerin oranı yalnız \%40 düzeyinde kalmıştır. Ancak işletmelerin çoğunluğu gıda satın almasında özellikle Helâl sertifikalı ürünleri tercih ettiklerini, banyo ve hatta kişisel temizlik malzemelerinde bile alkolsüz seçeneklere odaklanacak kadar hassas davrandıklarını belirtmişlerdir. $\mathrm{Bu}$ durum konaklama işletmelerinin Helâl uygulama konusunda hassas olduklarını fakat hassasiyetlerinin standardizasyon ve belgelendirme noktasında yetersiz kaldığını ortaya koymaktadır. Oysa ki bir işletmede turist için en önemli unsur "helal" üründür (Cankül vd., 2012, s.207) ve turist helal konseptli olduğunu bilerek geldiği bir otelde" helal gıda sertifikası" sorabilir.

Helal konseptli olarak kendini tanımlayan otellerde konaklayan turistler beklentileri karşılanmadığı için otelden mutsuz ayrılabilir buda Türkiye'deki helal turizmin yeterince gelişmediği düşüncesine yol açabilir. Bu tür olayların önlenebilmesi için Türkiye'de helal standartların oluşturulması ve bu standartları karşılayan otellere helal sertifika verilmesi gerekmektedir.

\section{SONUÇ VE ÖNERÍLER}

Helal turizm son yıllarda Türkiye'de yükselen bir turizm çeşidi olarak ortaya çıkmaktadır. Müslüman turistlerin dini yaşam tarzlarına uygun olarak ihtiyaç ve beklentilerini karşılamayı amaçlayan bu turizm türü son yıllarda ilgi görmüş ve bu alanda yapılan çalışmalar son yıllarda artış göstermiştir. Yeni bir tanım olduğu için helal turizmin ne olduğu, helal turizm işletmelerin taşıması gereken standartlar, müşterilerin beklentileri noktasında son birkaç yıldır sıkça çalışma yapılmaktadır. Yapılan çalışmalara ek olarak, bu çalışmanın temel amacı helal turizmin kavramsal çerçevesini ortaya koymak, Türkiye'de helal turizm gelişimini ele almak ve buna yönelik öneriler getirmektir. 
Dünyada sürekli artan Müslüman nüfusu ve gelir seviyesindeki artışlarla birlikte bu turizm çeşidi yükselen bir trend olabileceği ve Türkiye'nin de dini ve kültürel potansiyelini kullanarak bu trendi daha üst noktalara taşıyabileceği düşünülmektedir. Helal Turizm konseptin de hedef kitleyi çekme adına önemli adımlar atıldığında, Müslüman turistin büyük çoğunluğu ülkemizi tercih edebilir. Bu sayede 2023 hedefi olan turizm 86 milyar turizm geliri hedefine rahatlıkla ulaşılabilir. Çalışma konusu ile ilgili olarak elde edilen sonuçlar kapsamında geliştirilen öneriler şu şekildedir;

- Oteller için helal standartlar oluşturulabilir ve bu standartları karşılayan otellere sertifika verilebilir,

- Helal turizmin alt yapısının iyileştirilebilir ve üst yapılar zenginleştirilebilir,

- Girişimciler helal turizme teşvik edilebilir,

- Helal turizm 2023 için bir turizm politikası olarak ele alınabilir,

- Helal konseptli işletmeler için personel eğitilebilir bu alanda ilerlemek isteyen turizm öğrencilerinin stajları helal konseptli otellerde yaptırılabilir,

- Müslüman nüfusun yoğunlukta olduğu ülkelerden Türkiye'ye gelen turist sayısının her geçen gün arttı̆̆ görülmektedir bu artış tablo 3'te belirtilmiştir. Bu ülkelerden gelen turistlerin Müslüman olması sebebiyle bu kitleye yönelik pazarlama stratejilerinde ağırlık verilebilir ve bu da daha fazla turistin gelmesine ve turizm geliri elde edilmesine imkân sağlayabilir,

- Yurtdışı ve yurt içi helal turizm pazarlama çalışmaları yapılabilir.

- Helal turizme yönelik çalışmalar iyileştirildiğinde Türkiye helal turizmde 1. Sıraya yükselebilir ve 2023 stratejisinin gerçekleşmesinde önemli bir rol oynayabilir. Bu doğrultuda helal turizm stratejisi bir an önce belirlenmeli ve uygulanmalıdır. Bu araştırmanın helal turizm konusunda çalışma yapacak kişilere yol gösterici olması hedeflenmektedir. 


\section{KAYNAKÇA}

Akyol, M. ve Kılınç, Ö. (2014). Internet and Halal Tourism Marketing, International Periodical For The Languages, Literature and History of Turkish or Turkic, 9 (8), 171-186.

Arpacı, Ö., Uğurlu, K. ve Batman, O. (2015). Helal Konseptli otel işletmelerine yönelik yapılan müşteri şikayetleri üzerine bir araştırma, Bartın Üniversitesi İktisadi ve İdari Bilimler Fakültesi dergisi, 11, 181-198.

Arpacı, Ö. ve Batman, O. (2015), Helal konseptli otel işletmelerinin yüksek ve düşük sezonda algılanan hizmet kalitesinin müşteri sadakati ve müşteri değeri üzerine etkisi, seyahat ve otel işletmeleri dergisi, 12(3), 73-86.

Baran, Z. ve Batman, O.(2015). Gıda sektöründe tüketici beklentilerini karşılamada "Helal Gıda" Güvencesinin önemi, Uluslararası helal ürün ekonomisi sempozyumu,164-192.

Bilgin, Y. (2017). Helal Otel İşletmeleri İçin Bir Pazar Genişletme Stratejisi Olarak İşbirlikçi Pazarlama. 1. Uluslararası Helal Turizm Kongresi. 7-9 Nisan 2017 Antalya-Alanya

Bilgin, Y. ve Karakaş, A. (2017). Otel İşletmelerinin Helal Niteliğinin Müşteri Değerlendirmelerine Yansımaları: İstanbul'da Faaliyet Gösteren Helal Otellerden Bulgular. 1. Uluslararası Helal Turizm Kongresi. 7-9 Nisan 2017 Antalya-Alanya

Boğan, E., Batman, O. ve Sarışık, M. (2016). Helal turizmin kavramsal çerçevesi ve Türkiye'deki uygulamalar üzerine bir değerlendirme, $3 r d$ International Congress of Tourism \& Management Researches, Antalya, 1425-1440.

Büyükşalvarcı, A., Şapçılar, M. C. ve Adabalı M. M. (2016). Islam Dünyası Turizm Başkenti seçilmenin Konya Turizmine Etkileri, 9(45), 1054-1064.

Hacıoğlu, N., Oflaz, M., Buzlukçu, C. ve Kılıç, A. (2015). Yerli turistlerin helal( Muhafazakar) konseptli otellere yönelik tutumların belirlenmesi: Afyonkarahisar termal otelleri örneği, I. Eurasia International Tourism Congress: Current Issues, Trends, and Indicators, 489-502.

Koçyiğit, H. (2011). Türkiye'de seyehat etmenin Kur'ani boyutu, Atatürk Üniversitesi İlahiyat Fakültesi dergisi, 35, 126-143.

Köleoğlu, N., Erdil, Ș. T. ve Gezen, A. (2016), Tüketicilerin helal ürün algısı ve helal ürünleri satın alma niyetleri üzerine bir araştırma, Hitit Üniversitesi Sosyal Bilimler Enstitüsü Dergisi , 9 (1), 364- 378.

Kurtoğlu, R. ve Çiçek B. (2013). Tüketicilerin Helal Ürünler Hakkındaki Algılama, Tutum ve Beklentilerini Tespit Etmeye Yönelik Bir Araştırma, Eskişehir Osman Gazi Üniversitesi İktisadi ve İdari Bilimler Fakültesi dergisi, 8 (3), 181-205.

Met, Ö., Özdemir, İ. M. ve Aydemir, B. (2013). İslami otellerin ürün nitelikleri: Türkiye örneği, 
International Conference on Religious Tourism and Tolerance, Konya, 651-662.

Oflaz, M. (2015). Turistik ürün çeşidi olarak helal turizm konsepti uygulayan konaklama tesislerinde müşteri algıları, Yüksek Lisans Tezi, Balıkesir Üniversitesi, Balıkesir.

Özaltaş Serçek, G., Karakaş, A. ve Serçek, S. (2017). Tüketicilerin Helal Turizm Konsepti Uygulamalarına Yönelik Algıları. 1. Uluslararası Helal Turizm Kongresi. 7-9 Nisan 2017 AntalyaAlanya

Pamukçu, H. ve Arpacı, Ö. (2015). Helal konseptli otel işletmeleri: Türkiye'deki mevcut durum üzerine bir araştırma, 1.Uluslararası Türk Dünyası Sempozyumu, Kastamonu, 319-331.

Pamukçu, H. ve Sarış̧ı, M. (2016). Helal Turizm Kavramı ve Gelişimi Üzerine Bir Değerlendirme , 17.Ulusal Turizm Kongresi, Ankara, 758, 99-109.

Süt, A. (2014). Islam ve Turizm ilişkisi, International periodical for the languages, Literature and History of Turkish or Turkic, 9(11), 479-497.

Tanrısever, C., Batman, O. ve Pamukçu, H.(2015), Turizmde yeni eğilimler, 2nd International Congress of Tourism \& Management Researches, 457 -475.

Tekin, Ö. A. ve Yılmaz, E. (2016). İslami turizm konseptine hizmet veren konaklama işletmeleri zerine bir inceleme, Uluslararast Sosyal Araşstrmalar Dergisi, 9(42), 2046-2058).

Yeşiltaş, M., Cankül, D. ve Temizkan, R. (2012).Otel seçiminde dini hayat tarzlarının etkisi, Elektronik Sosyal Bilimler Dergisi, 39, 193-217.

Yücebaş, S. (2012). Türkiye'de muhafazakarlığın gündelik yaşam estetiği, İnsan Bilim Dergisi, $1(2), 62-80$.

Zengin, B. (2015). Turizm İşletmeleri, 3.Baskı, İstanbul: Değişim Yayınları.

\section{Internet kaynakları}

http://www.tdk.gov.tr/index.php?option=com_gts\&kelime=HARAM E.T 25.12.2016

http://whtsexpo.com/ E.T 18.01.2.2017

https://bilgibirikimi.net/2012/10/24/musluman-ulkeler-dunyada-kac-musluman-ulke-vardir/ E.T 18.01.2017

http:/guzelbil.com/din/dunya-uzerinde-kac-tane-islammusluman-ulke-vardir.html E.T 18.01.2017

http://newsroom.mastercard.com/asia-pacific/files/2016/03/Report-MasterCard-CrescentRating-

Global-Muslim-Travel-Index-2016.pdf E.T 20.01.2016

http://www.islamitatilyerleri.net/tr/yeni-acilan-oteller E.T. 20.01.2017

http://www.islamihotels.com/islami-otellerin-altin-yili.php E.T 20.01.2017

http://www.diyanet.gov.tr/dijitalyayin/ilmihal_cilt_1.pdf E.T 21.02.2017 